\title{
Secretion of nitrogen compounds into the isolated caecum and colon of sheep
}

\author{
Beata Skiba, J. Kowalczyk and Teresa Żebrowska
}

\author{
The Kielanowski Institute of Animal Physiology and Nutrition, \\ Polish Academy of Sciences \\ 05-110 Jablonna, Poland
}

(Received 10 August 1995; accepted 6 November 1995)

\begin{abstract}
The experiments were carried out on 8 one-year-old rams of about $45 \mathrm{~kg}$ body weight, 4 with a surgically isolated caecum pouch $(250 \mathrm{ml})$ and 4 with an approximately $1 \mathrm{~m}$ long isolated colon loop. The animals were fed a basal diet containing $11 \% \mathrm{CP}$ or supplemented with urea to 14 or $17 \%$ $\mathrm{CP}$. To study the influence of hypo- and hypertonic solutions on nitrogen compound secretion, the isolated caecum pouch was washed with antibiotics and filled with $0.45,0.9,1.8$ or $2.7 \% \mathrm{NaCl}$ solutions. Samples were taken after $4 \mathrm{~h}$ to determine secreted nitrogen compounds. Increasing the $\mathrm{NaCl}$ concentration from 0.45 to $1.8 \%$ had no effect, but at $2.7 \%$ it significantly raised the amount of total- $\mathrm{N}$ secreted into the caecum from 5.4 to 14.3 ; protein- $\mathrm{N}$ rose from 3.8 to 11.9 and urea- $\mathrm{N}$ from 1.5 to $2.8 \mathrm{mg} / \mathrm{h}$ for 0.45 and $2.7 \% \mathrm{NaCl}$, respectively. The influence of the $\mathrm{CP}$ level in the diet was studied at $0.9 \% \mathrm{NaCl}$ solution in the caecum and colon. Increasing the level of $\mathrm{CP}$ in the diet from 11 to $17 \%$ caused an insignificant rise of total- $\mathrm{N}$ secretion into the caecum pouch from 5.6 to 6.1 ; protein- $\mathrm{N}$ from 3.4 to 4.7 ; urea- $\mathrm{N}$ from 1.6 to $1.7 \mathrm{mg} / \mathrm{h}$ and the blood urea- $\mathrm{N}$ level from 10.5 to $16.4 \mathrm{mg} / 100 \mathrm{ml}$, respectively. Animals fed diets with 11 or $14 \% \mathrm{CP}$ secreted as follows into the colon loop: 3.8 and 4.3 total- $\mathrm{N} ; 2.9$ and 2.8 protein- $\mathrm{N} ; 0.8$ and $1.4 \mathrm{mg} / \mathrm{h}$ urea- $\mathrm{N}$, with a concomitant blood urea-N level of 10.7 and $14.5 \mathrm{mg} / 100 \mathrm{ml}$, respectively for the diets. Injection of $40 \mathrm{ml} 7.5 \%$ urea solution into the jugular vein of each animal every hour for $5 \mathrm{~h}$ progressively increased the level of urea- $\mathrm{N}$ from 11 to $26 \mathrm{mg} / 100 \mathrm{ml}$. The respective values of urea- $\mathrm{N}$ secreted into the caecum pouch were 2 and $11 \mathrm{mg} / \mathrm{h}$ and into the colon loop 2.2 and $3.3 \mathrm{mg} / \mathrm{h}$.
\end{abstract}

KEY WORDS: sheep, nitrogen, secretion, caecum, colon

\section{INTRODUCTION}

Information on the secretion of urea and other nitrogen compounds into the large intestine of ruminants is rather scarce and contradictory. It was demonstrated on heifers that the ammonia level in the caecum content increases after 
intravenous infusion of urea (Kulasek, $1966 \mathrm{a}, \mathrm{b}$ ) which could be a consequence of urea transfer from blood into the caecum and its hydrolysis to ammonia by urease of bacterial origin (Faichney, 1968). Their findings were corroborated by Nolan et al. (1976) who demonstrated rapid increase of enrichment with ${ }^{15} \mathrm{~N} \%$ excess in the caecum content of sheep given ${ }^{15} \mathrm{~N}$-labelled urea into the blood. However, quantitative data defining the magnitude of nitrogen compound secretion into the large intestine are few and often discrepant.

The aim of this study was to estimate the amount and type of nitrogen compounds secreted into the caecum and colon of sheep depending on the nitrogen content in the ration and urea level in the blood.

\section{MATERIAL AND METHODS}

\section{Animals}

The experiments were carried out on 8 one-year-old rams of about $45 \mathrm{~kg}$ body weight. Four of them were provided with isolated pouches of the caecum with a cannula inserted into the end of the pouch according to Hecker (1974). The other 4 animals were prepared with an isolated loop of the spiral colon. An approximately $1 \mathrm{~m}$ long section of the spiral colon was cut at each end and equipped with $T$-piece cannulas. The proximal and distal end of colon were anastomosed end-to-end to allow digesta to pass. The isolated part of the caecum and colon were rinsed 3 times a day with $0.9 \% \mathrm{NaCl}$ solution containing $0.33 \mathrm{~g}$ streptomycin, $0.33 \mathrm{~g}$ neomycin and $10000 \mathrm{I} . \mathrm{U}$. penicillin per litre. The animals were kept for a two-week recovery period in individual pens, fed meadow hay with free access to water.

\section{Experiment 1}

The rams with isolated caecums were given a basal diet containing $11 \%$ crude protein (Table 1) consisting of $700 \mathrm{~g}$ meadow hay and $400 \mathrm{~g}$ barley. The ration was distributed over two equal meals at 8.00 and $15.00 \mathrm{~h}$ and given for at least two weeks before the experiment started. The pouch of the caecum was filled with $250 \mathrm{ml}$ solutions containing $4.5 ; 9.0 ; 18.0$ or $27.0 \mathrm{~g} \mathrm{NaCl} / \mathrm{l}$ and $2 \mathrm{~g} \mathrm{PEG}-4000 / 1$. Each solution was introduced into the caecum after the morning meal during 5 consecutive days. Twenty milliliter samples of liquid were withdrawn 2 and $4 \mathrm{~h}$ after the solution was introduced and stored in deep freeze for analysis. The isolated caecum was rinsed with a $0.9 \% \mathrm{NaCl}$ solution containing antibiotics and most of the solution was removed from the pouch by a syringe connected to soft tubing. 
TABLE 1

Daily rations and chemical composition

\begin{tabular}{lccc}
\hline \multirow{2}{*}{ Indices } & Basal diet & \multicolumn{2}{c}{ Diets with urea } \\
\cline { 2 - 4 } & I & II & III \\
\hline Meadow hay, g & 700 & 700 & 700 \\
Barley, g & 400 & 400 & 400 \\
Urea, g & - & 10 & 20 \\
Chemical composition, DM \% & & & \\
$\quad$ organic matter & 94.7 & 95.1 & 95.2 \\
$\quad$ crude protein & 11.1 & 14.1 & 17.1 \\
crude fibre & 24.8 & 24.8 & 24.8 \\
N-free extractives & 56.4 & 55.8 & 54.9 \\
\hline
\end{tabular}

\section{Experiment 2}

The experiment was conducted in two periods: during the first period the animals with the caecum pouch and those with the isolated colon loop were fed as in Experiment 1. In the second period, the animals with the caecum pouch were given diet III consisting of $700 \mathrm{~g}$ meadow hay and $400 \mathrm{~g}$ urea-treated barley containing $20 \mathrm{~g}$ of urea. The animals with the colon loop received diet II of a similar composition but containing $10 \mathrm{~g}$ urea (Table 1).

During a 5-day period, $250 \mathrm{ml}$ of $0.9 \% \mathrm{NaCl}$ solution containing $2 \mathrm{~g} / 1 \mathrm{PEG}$ were introduced into the isolated caecum after the morning meal and samples of $20 \mathrm{ml}$ were withdrawn at 2 and $4 \mathrm{~h}$ afterwards. The isolated colon loops were perfused with solution as in animals with a caecum pouch by means of a peristaltic pump at the rate of $5 \mathrm{ml} / \mathrm{min}$ for $5 \mathrm{~h}$. The perfusate was collected into a bottle kept on ice, measured every hour and stored for analysis.

\section{Experiment 3}

The experiment was conducted on animals with caecum pouches and colon loops given diet I as in Experiment 1, and the caecum pouches and colon loops were perfused as in Experiment 2. Forty $\mathrm{ml}$ of $7.5 \%$ urea solution were introduced into the jugular vein every hour for $5 \mathrm{~h}$. Blood samples from the jugular vein were taken every $30 \mathrm{~min}$ after urea infusion. The samples of liquid from the caecum and colon were taken as in Experiment 2.

\section{Analytical methods}

Total nitrogen was estimated by the Kjeldahl method, protein- $\mathrm{N}$ by Bernstein, urea-N and ammonia by the Conway method (1954), PEG according to Hydén (1955). 


\section{RESULTS}

\section{Experiment 1}

The secretion of nitrogen compounds into the caecum increased as the concentration of $\mathrm{NaCl}$ in the administered solutions rose (Table 2). The amount of total- $\mathrm{N}$ secreted during $1 \mathrm{~h}$ rose significantly $(\mathrm{P}<0.01)$ from 5.41 to $14.3 \mathrm{mg}$ at 0.45 and $2.7 \% \mathrm{NaCl}$ solutions, respectively; this rise was due mainly to the increased amount of protein- $\mathrm{N}$. The amount of urea secreted into the caecum was similar for $0.45 ; 0.9$ and $1.8 \% \mathrm{NaCl}$ solutions, but doubled when $2.7 \% \mathrm{NaCl}$ solution was given into the isolated caecum $(P<0.05)$.

TABLE 2

The amount of total- $\mathrm{N}$, protein- $\mathrm{N}$ and urea- $\mathrm{N}$ secreted into the isolated caecum depending on $\mathrm{NaCl}$ concentration (Mean $\pm \mathrm{SD} ; \mathrm{n}=4), \mathrm{mg} / \mathrm{h}$

\begin{tabular}{lcccc}
\hline \multicolumn{5}{c}{$\mathrm{NaCl}$ concentration, \% } \\
\hline Nitrogen fraction & 0.45 & 0.90 & 1.80 & 2.70 \\
\hline Total-N & $5.41^{\mathrm{A}} \pm 2.1$ & $5.59^{\mathrm{A}} \pm 0.5$ & $7.90^{\mathrm{A}} \pm 2.3$ & $14.3^{\mathrm{B}} \pm 7.7$ \\
Protein-N & $3.79^{\mathrm{A}} \pm 0.9$ & $3.41^{\mathrm{A}} \pm 0.2$ & $6.36^{\mathrm{B}} \pm 1.7$ & $11.9^{\mathrm{C}} \pm 2.3$ \\
Urea-N & $1.49^{\mathrm{a}} \pm 0.9$ & $1.62^{\mathrm{A}} \pm 0.3$ & $1.48^{\mathrm{a}} \pm 0.5$ & $2.82^{\mathrm{b}} \pm 1.2$ \\
\hline
\end{tabular}

in rows: $\mathrm{a}, \mathrm{b}-\mathrm{P}<0.05 ; \mathrm{A}, \mathrm{B}, \mathrm{C}-\mathrm{P}<0.01$

The movement of water across the wall of the caccum was affected by the $\mathrm{NaCl}$ concentration in the solution used (Table 3 ). About $20 \%$ of the water was absorbed from the caecum during $1 \mathrm{~h}$ when the intestine was filled with $0.45 \%$ $\mathrm{NaCl}$, while greater concentrations of $\mathrm{NaCl}$ caused secretion of water into the lumen of the caecum, with water secretion increasing as $\mathrm{NaCl}$ concentrations rose.

TABLE 3

Changes of the amount of water $(\mathrm{ml} / \mathrm{h})$ and PEG concentration (\%) in the isolated caecum at different $\mathrm{NaCl}$ concentration in administercd solution (Mcan $\pm \mathrm{SD} ; \mathrm{n}=4$ )

\begin{tabular}{ccccc}
\hline Concentration of $\mathrm{NaCl}$ & $\begin{array}{c}\text { Changes in water content } \\
\text { in the caecum }\end{array}$ & \multicolumn{3}{c}{ PEG concentration } \\
\cline { 3 - 5 } & $-11.13 \pm 8.4$ & $0 \mathrm{~h}$ & $2 \mathrm{~h}$ & $4 \mathrm{~h}$ \\
\hline 0.45 & $+9.00 \pm 1.4$ & 0.21 & 0.22 & 0.23 \\
0.90 & $+19.92 \pm 11.7$ & 0.21 & 0.20 & 0.18 \\
1.80 & $+31.42 \pm 13.9^{\circ}$ & 0.19 & 0.17 & 0.14 \\
2.70 & 0.19 & 0.15 & 0.12 \\
\hline
\end{tabular}


TABLE 4

The amount of total- $\mathrm{N}$, protein- $\mathrm{N}$ and urea- $\mathrm{N}(\mathrm{mg} / \mathrm{h} / 250 \mathrm{ml})$ secreted into the isolated caccum and urea- $\mathrm{N}$ concentration $(\mathrm{mg} / 100 \mathrm{ml})$ in blood $(\mathrm{Mcan} \pm \mathrm{SD} ; \mathrm{n}=4)$

\begin{tabular}{lcc}
\hline \multirow{2}{*}{ Nitrogen } & \multicolumn{2}{c}{ Protein level in diets, \% } \\
\cline { 2 - 3 } & 11 & 17 \\
\hline Total-N & $5.59 \pm 0.5$ & $6.11 \pm 2.1$ \\
Protein-N & $3.41 \pm 0.2$ & $4.68 \pm 1.3$ \\
$\%$ of total-N & 61 & 77 \\
Urea-N & $1.62 \pm 0.3$ & $1.73 \pm 0.9$ \\
$\%$ of total-N & 30 & 28 \\
Urea-N in blood & $10.45 \pm 0.5$ & $16.40 \pm 5.1$ \\
\hline
\end{tabular}

\section{Experiment 2}

The amount of total- $\mathrm{N}$, protein- $\mathrm{N}$ and urea- $\mathrm{N}$ secreted into the isolated caecum was not influenced significantly by the level of nitrogen in the diets $(P>0.05)$, however it did show an upward tendency (Table 4$)$. The proportion of urea-N in total nitrogen in the effluent from the caecum was similar irrespective of the diet, but the proportion of protein- $\mathrm{N}$ rose from 61 to $77 \%$ with increasing crude protein level in the diet. The amount of total-N secreted into the colon loop rose from 3.8 to $4.3 \mathrm{mg}$ as nitrogen level in the diets increased. This increase, however, was not statistically significant and was caused mostly by increased secretion of urea- $\mathrm{N}(\mathrm{P}<0.05)$. It was accompanied by increasing blood urea- $\mathrm{N}$ level (Table 5). Protein- $\mathrm{N}$ contribution in total- $\mathrm{N}$ in the effluent from the isolated colon decreased from 76 to $65 \%$ with increasing level of crude protein in the diet.

TABLE 5

The amount of total- $\mathrm{N}$, protein-N and urea- $\mathrm{N}(\mathrm{mg} / \mathrm{h} / 250 \mathrm{ml})$ secreted into the isolated colon and urea- $\mathrm{N}$ concentration $(\mathrm{mg} / 100 \mathrm{ml})$ in blood $(\mathrm{Mean} \pm \mathrm{SD} ; \mathrm{n}=4)$

\begin{tabular}{lcc}
\hline \multirow{2}{*}{ Nitrogen } & \multicolumn{2}{c}{ Protein level in diets, \% } \\
\cline { 2 - 3 } & 11 & 17 \\
\hline Total-N & $3.77 \pm 1.3$ & $4.32 \pm 1.1$ \\
Protein-N & $2.90 \pm 1.1$ & $2.75 \pm 1.3$ \\
$\%$ of total-N & 77 & 64 \\
Urea-N & $0.83^{\mathrm{a}} \pm 0.2$ & $1.40^{\mathrm{b}} \pm 0.5$ \\
$\%$ of total-N & 22 & 32 \\
Urea-N in blood & $10.70^{\mathrm{a}} \pm 0.5$ & $14.50^{\mathrm{b}} \pm 2.1$ \\
\hline
\end{tabular}

a, $\mathrm{b}-\mathrm{P}<0.05$ 
TABLE 6

The amount of total- $\mathrm{N}$ and urea- $\mathrm{N}(\mathrm{mg})$ secreted into the caecum filled with $0.9 \% \mathrm{NaCl}$ solution during urea infusion into the jugular vein, and the level of urea in blood $(\mathrm{mg} / 100 \mathrm{ml})(\mathrm{Mean} \pm \mathrm{SD})$

\begin{tabular}{ccccc}
\hline Time, $\mathrm{h}$ & Total-N & Urea-N & $\begin{array}{c}\text { Urea-N as \% } \\
\text { of total-N }\end{array}$ & Urea-N in blood \\
\hline 0 & $20.5 \pm 8.8$ & $2.2 \pm 1.3$ & 10.7 & 10.6 \\
1 & $29.9 \pm 19.8$ & $4.1 \pm 2.6$ & 13.7 & 13.9 \\
2 & $40.8 \pm 31.6$ & $4.7 \pm 2.6$ & 11.5 & 17.0 \\
3 & $45.2 \pm 18.4$ & $7.2 \pm 2.7$ & 15.9 & 19.1 \\
4 & $56.0 \pm 8.6$ & $8.8 \pm 2.5$ & 15.7 & 20.7 \\
5 & $65.2 \pm 8.9$ & $10.8 \pm 2.3$ & 16.6 & 23.7 \\
\hline
\end{tabular}

\section{Experiment 3}

During infusion of urea into the jugular vein the amount of total and urea- $\mathrm{N}$ entering the caecum rose from 20.5 and $2.2 \mathrm{mg}$ to 65.2 and $10.8 \mathrm{mg}$, respectively, and was accompanied by increased blood concentrations of urea-N (Table 6). The correlation coefficient between blood urea- $\mathrm{N}$ concentration and the amount of urea-N secreted into the caecum was $r^{2}=0.36(P<0.05)$. Only traces of ammonia content were found in the samples from the caecum.

TABLE 7

The amount of total- $\mathrm{N}$ and urea- $\mathrm{N}(\mathrm{mg})$ secreted into the colon and the level of urea in blood ( $\mathrm{mg} \mathrm{N} / 100 \mathrm{ml}$ ) during urea infusion into the jugular vcin (Mean $\pm \mathrm{SD}$ )

\begin{tabular}{ccccc}
\hline Time, h & Total-N & Urea-N & $\begin{array}{c}\text { Urea-N as \% } \\
\text { of total-N }\end{array}$ & Urea-N in blood \\
\hline 0 & - & - & & $11.7 \pm 2.6$ \\
1 & $15.6 \pm 2.5$ & $2.2 \pm 0.6$ & 14.3 & $17.7 \pm 2.8$ \\
2 & $8.7 \pm 3.1$ & $3.2 \pm 1.1$ & 36.8 & $18.4 \pm 2.6$ \\
3 & $8.0 \pm 2.7$ & $2.7 \pm 0.7$ & 35.0 & $21.1 \pm 2.2$ \\
4 & $7.6 \pm 2.5$ & $2.9 \pm 0.5$ & 38.8 & $25.4 \pm 1.8$ \\
5 & $7.8 \pm 1.9$ & $3.3 \pm 0.6$ & 43.4 & $26.8 \pm 2.7$ \\
\hline
\end{tabular}

In animals with isolated colon loops infusion of urea solution into the jugular vein raised the blood level of urea, similarly as in those animals with isolated caecum pouches, however secretion of urea into the loop increased only slightly (Table 7). The amount of total- $\mathrm{N}$, protein- $\mathrm{N}$ and urea-N secreted during $24 \mathrm{~h}$ calculated using data of the Tables 4 and 5 and assuming that secretion of nitrogen compounds into the caecum and colon remained constant throughout the day, is presented in Table 8 . 
TABLI: 8

Average calculated amount of total- $\mathrm{N}$, protein- $\mathrm{N}$ and urea- $\mathrm{N}(\mathrm{mg} / 24 \mathrm{~h})$ sccretcd into the isolated caecum and colon when the diets containing $11 \%$ or $17 \%$ crude protein was fed

\begin{tabular}{lcccc}
\hline & \multicolumn{2}{c}{ Caccum } & \multicolumn{2}{c}{ Colon $^{2}$} \\
\cline { 2 - 5 } & $11 \% \mathrm{CP}$ & $17 \% \mathrm{CP}$ & $11 \% \mathrm{CP}$ & $17 \% \mathrm{CP}$ \\
\hline Total-N & 134.2 & 146.6 & 316.7 & 362.9 \\
Protein-N & 81.8 & 112.3 & 243.6 & 231.0 \\
Urea-N & 38.9 & 41.5 & 69.7 & 117.6 \\
\hline
\end{tabular}

mean capacity of isolated caccum was $250 \mathrm{ml}$

2 assuming length of colon was $3.5 \mathrm{~m}$

\section{DISCUSSION}

Studies on secretion of nitrogen compounds into the large intestine are difficult because of the high proteolytic activity of the microflora and degradation of urea to ammonia. Therefore in this study, the experiments were carried out on sheep with isolated caecum and colon devoid of digesta and washed with a solution containing antibiotics to stop development of microflora. Lack of microflora in the isolated caecum and colon was confirmed by presence of secreted urea and absence of ammonia in the liquid from these parts of the intestine. However, some adverse effects of antibiotic treatment on intestinal function have been reported. Studies by Madge (1969) and Coales (1973) have shown the thinning of the intestinal wall resulting from the antibiotics treatment, usually causing increased intestinal transport and cell permeability.

Factors influencing urea secretion into the small and large intestine are little explored. The results obtained in this study showed that the amount of urea secreted into the caecum depended on the $\mathrm{NaCl}$ concentration in the solution given into the isolated caecum. With concentrations of $\mathrm{NaCl}$ increasing from 0.45 to $2.7 \%$, urea secretion increased almost twofold but intermediate concentrations did not markedly influence urea secretion. This may suggest that urea is secreted into the large intestine by simple diffusion. It is accepted that diffusion is the main process by which urea is transported to the rumen (Houpt, 1970; Harmeyer and Martens, 1980; Obara et al., 1991). Houpt and Houpt (1968) reported that increased concentrations of $\mathrm{NaCl}$ disrupted the epithelial cells and, as a consequence, urea transport rose significantly. It is possible that the mechanism of urea transport throughout the walls of other than rumen parts of the gastrointestinal tract is passive diffusion.

It has been assumed that urea secretion into the forestomachs of ruminants varies with the composition of the diet, but for most of the commonly used feeds it fluctuates between 45 to $60 \%$ of the total amount of urea secreted into the gastrointestinal tract (Kowalczyk et al., 1975; Harmeyer and Martens, 1980; 
Kennedy and Milligan, 1980). Urea movement across the wall of the caecum (Nolan et al., 1976) and the small intestine was demonstrated to be quantitatively important and constituted $85 \%$ of urea secreted into the whole intestine in sheep given a hay and barley diet (Várady et al., 1979). Żebrowska and Kowalczyk (1991) reported that about $5.7 \mathrm{~g} / \mathrm{d}$ of urea- $\mathrm{N}$ is secreted into the small intestine of sheep.

Our experiments have shown that changes of $\mathrm{N}$-content in diets can only slightly modify the amount of nitrogen compounds secreted into the large intestine. Dixon and Nolan (1983) and Dixon and Milligan (1984) proved that less total- $\mathrm{N}$ was transported into the caecum and proximal colon when sheep were fed diets containing 10 than $23 \mathrm{~g} \mathrm{~N} / \mathrm{d}$. Other authors reported that addition of easily fermenting feeds into the caecum can increase urea transport into this part of intestine-(Bergner et al., 1985; Sommer et al., 1986; Kijora et al., 1992). Siddons et al. (1985) reported that the level of nitrogen in the diet, varying from 11.0 to $19.5 \mathrm{~g} \mathrm{~N} / \mathrm{d}$, had no effect on urea transport into the whole gastrointestinal tract.

It is interesting to note that the amount of protein- $\mathrm{N}$ secreted into the isolated colon was independent of the nitrogen level in the diet, whereas the amount of urea-N rose significantly with increasing levels of dietary nitrogen. This may suggest that protein nitrogen originated mainly from shedding epithelial cells, while increased secretion of nitrogen into the colon was caused by greater urea transport across the intestinal wall. Dixon and Nolan (1983) suggest that the amount of nitrogen in the colon originating from epithelium cells is large and could reach $0.8 \mathrm{~g} \mathrm{~N} / \mathrm{d}$. Żebrowska and Kowalczyk (1991) have shown a similar dependence in their study on nitrogen compound secretion into the small intestine. It is difficult to explain why the higher level of nitrogen did not affect the amount of urea secreted into the caecum, although this was proved for the colon.

Our study clearly showed that the amount of urea- $\mathrm{N}$ secreted into the caecum and colon was related to the blood urea level, which is in agreement with results of Hecker (1971), Nolan and Leng (1972), Engelhardt et al. (1984) and Żebrowska and Kowalczyk (1991) indicating that a substantial quantity of plasma urea enters the post-ruminal part of digestive tract of sheep. Hecker (1971) demonstrated a close correlation between urea concentration in blood and ammonia, originating from endogenous urea, in the ileum and colon of sheep. Engelhardt et al. (1984) also found a high positive correlation between urea level in blood and urea secretion into the colon but the amount of urea secreted was low $(0.1$ to $0.3 \mathrm{mmol} / \mathrm{h})$ suggesting that permeability of the colon epithelium for urea is rather low.

Assuming that secretion of urea into the large intestine is constant throughout the day, the approximate amount of urea- $\mathrm{N}$ secreted during $24 \mathrm{~h}$ into the isolated 
part of caecum was estimated on the average only about $40 \mathrm{mg}$ urea- $\mathrm{N} / 250 \mathrm{ml} / \mathrm{d}$ (Table 8). Nolan et al. (1976) estimated that urea-N secreted into the gastrointestinal tract was $5.3 \mathrm{~g} \mathrm{~N} / \mathrm{d}$ but only $1.06 \mathrm{~g}$ was from the caecum. This discrepancy could result from the fact that Nolan's study referred to the whole intact caecum while our experiment was carried out on the isolated caecum with a capacity of $250 \mathrm{ml}$. However, even adjusting the estimated value of $40 \mathrm{mg}$ to the volume of the whole caecum, which is usually about 11 , an approximate value of $0.16 \mathrm{~g}$ urea- $\mathrm{N}$ is obtained, which is still about 6 times less than the above mentioned value given by Nolan et al. (1976). A value higher than $20 \mathrm{mg} \mathrm{N} / \mathrm{d}$ secreted into the whole large intestine was reported by Dixon and Milligan (1987), but Fejes and Várady (199l) found a value of $0.25 \mathrm{~g} \mathrm{~N}$.

\section{REFERENCES}

Bergner H., Simon O., Sommer A., Gorsch R., Cerešnáková Z., Chrastinova L., Szakacs J., Stoyke M., 1985. Studies on nitrogen metabolism of the large intestine of ruminants. 1. Metabolism of intravenous infused ${ }^{15} \mathrm{~N}$-urea without additional carbohydrate supply to the large intestine. Arch. Anim. Nutr. 35, 733-745

Coates M.E., 1973. Gnotobiotic animals in nutrition research. Proc. Nutr. Soc. 32, 53-58

Conway E.J., 1954. Microdiffusion Analysis and Volumetric Error. Crosby Lockwood, London

Dixon R.M., Milligan L.P., 1984. Nitrogen kinetics in the large intestine of shecp given bromegrass pellets. Can. J. Anim. Sci. 64, 103-111

Dixon R.M., Nolan J.V., 1983. Studies on the large intestine of sheep. 3. Nitrogen kinetics in the sheep given chopped luccrne (Medicago sativa) hay. Brit. J. Nutr. 50, 757-768

Engelhardt W., Hinderer G., Rechkemmer G., 1984. Urea secretion into the colon of sheep and goat. J. Exp. Physiol. 69, 469-475

Faichney G.J., 1968. Volatile fatty acids in the caecum of sheep. Aust. J. Biol. Sci. 21, 177-180

Feješ J., Várady J., 1991. Endogenous urea recycling in sheep. In: J. Koppel, M. Baran (Editors), Animal Physiology. Institute of Animal Physiology, Slovak Academy of Sciences, Košice, Czechslovakia, pp. 121-135

Harmayer J., Martens H., 1980. Aspects of urea metabolism in ruminants with reference to the goat. J. Dairy Sci. 63, 1707-1728

Hecker J.F., 1971. Ammonia in the large intestine of herbivores. Brit. J. Nutr. 26, 135-145

Hecker J.F., 1974. Experimental Surgery on Small Ruminants. Butterworth and Co., London, pp. 133-135

Houpt T.R., Houpt K.A., 1968. Transfer of urea across the rumen wall. Amer. J. Physiol. 214. 1296-1303

Hydén S., 1955. A turbidimetric method for the determination of higher polyethylene glycols in biological materials. Kungl. Landtbr.Högsk. Ann. 22, 139-145

Kennedy P.M., Milligan L.P., 1980. The degradation and utilization of endogenous urea in gastrointestinal tract of ruminants. Can. J. Anim. Sci. 60, 205-221 
Kijora C., Bergner H., Bartelt .J., Sakacs J., Sommer A., Charastinova L., Čerešnáková Z., 1992. Metabolism of intravenously infused ${ }^{15} \mathrm{~N}$-urea supplemented with pectin in heifers. Arch. Anim. Nutr. 42, 287-300

Kowalczyk J., Havassy I., Otwinowska A., Košta K., 1975. Passage of intravenously administered ${ }^{15} \mathrm{~N}$ urea into the digestive tract and its excretion in the sheep. Acta physiol. pol. 26, 299-306

Kulasek G., 1966a. Digestive processes in the large intestine of heifers. 1. Mctabolism and absorption of nitrogen compounds and volatile fatty acids in the large intestine (in Polish). Rocz. Nauk rol., Ser. B, 88, 369-385

Kulasek G., 1966b. Digestive processes in the large intestine of heifers. 2. Absorption of ammonium ions from the caecum and transfer of urea from the blood into the caecum content (in Polish). Rocz. Nauk rol., Ser. B, 88, 386-395

Madge D.S., 1969. Effect of antibiotics on intestinal absorption in mice. Brit. J. Nutr. 23, 637-646 Nolan J.V., Leng R.A., 1972. Dynamic aspects of ammonia and urea metabolism in sheep. Brit. J. Nutr. 27, 177-194

Nolan J.V., Norton B.W., Leng R.A., 1976. Dynamic aspects of ammonia and urea metabolism in sheep. Brit. J. Nutr. 35, 127-147

Obara Y., Dellow D.W., Nolan J.V, 1991. The influence of energy reach supplements on nitrogen kinetics in ruminants. In: T.Tsuda, Y.Sasaki, R. Kawashima (Editors), Physiological aspects of digestion and metabolism in ruminants. Proceedings of $7^{\text {th }}$ International Symposium on Ruminant Physiology, Academic Press, pp. 515-539

Siddons R.C., Nolan J.V., Beever D.E., MacRae J.C., 1985. Nitrogen digestion and metabolism in sheep consuming diets containing contrasting forms and levels of N. Brit. J. Nutr. 54, 175-187

Sommer A., Čcrešnáková Z., Szakacs J., Chrastinova L., Bregner H., Simon O., 1986. Studies on nitrogen metabolism of the large intestine of ruminants. 2. Metabolism of intravenous infused ${ }^{15} \mathrm{~N}$-urea in case of an additional supply to the large intestine with a fermentable source. Arch. Anim. Nutr. 36, 639-651

Várady J., Bod'a K., Tasenov K., Feješ J., 1979. Nitrogen secretion into the digestive tract in shecp. Ann. Rech. Vet. 10, 448-450

Várady J., Feješ J., 1987. Endogenous urea in digestive tract and its significance in nitrogen metabolism in ruminants (in Slovak). Veter. Med. (Praha) 32, 195-200

Żebrowska T., Kowalczyk J., 1991. Nitrogen secretion into loops of small intestine in conscious sheep. J. Anim. Physiol. Anim. Nutr. 65, 133-139

\section{STRESZCZENIE}

\section{Sekrecja związków azotowych do jelita grubego owiec}

Doświadczenic przeprowadzono na ośmiu $45 \mathrm{~kg}$, jednorocznych tryczkach: $4 \mathrm{z}$ izolowną petlą okrężnicy o dlugości około $1 \mathrm{~m}$ oraz $4 \mathrm{z}$ izolowanym jclitem ślepym o pojemności około 0,251 . Zwier द̨ta utrðymywano na dawce podstawowej zawierającej $11 \%$ lub uzupełnionej mocznikiem do 14 lub $17 \%$ białka ogólnego. Podanie hipo-i hipertonicznych, od 0,45 do 1,8\% roztworów $\mathrm{NaCl}$ do przemytych roztworem antybiotyków izolowancj części jelita ślcpego i okrężnicy miało niewielki wpływ na sekrecję związków azotowych do jelita, natomiast podanie $2,7 \%$ roztworu istotnie zwiększyło wydzielanie do izolowanego jelita słlepego $\mathrm{N}$-ogólnego z 5,4 do 14,3; N-bialkowego z. 3,8 do 11,9 a $\mathrm{N}$-mocznikowego z 1,5 do $2,8 \mathrm{mg} /$ godz. Wpływ poziomu białka ogólncgo w diecie na 
sekrecję związk ów azotowych badano przy podawaniu do jclit $0.9 \%$ roztworu $\mathrm{NaCl}$. Po zwiększeniu poziomu białka w diecie z 11 do 17\% ilość azotu wydzielanego do izolowanego jelita ślepego wzrastała, odpowiednio dla diet: $\mathrm{N}$-ogólnego z 5,6 do 6,1 ; $\mathrm{N}$-białkowego $\% 3,4$ do 4,7, a N-mocznikowego z 1,6 do 1,7 mg N/godz. przy wzroście poziomu N-mocznika we krwi z 10,5 do $16,4 \mathrm{mg} / 100 \mathrm{ml}$. Sekrecja do pętli okrężnicy przy skarmianiu dict o zawartości białka 11 i $14 \%$ wynosiła, odpowiednio: N-ogólnego - 3,8 i 4,3; N-białkowego - 2,9 i 2,8, N-mocznika - 0,8 i 1,4 mg/godz., przy poziomie $\mathrm{N}$-mocznika we krwi 10,7 i 14,5 $\mathrm{mg} / 100 \mathrm{ml}$. Wplyw poziomu mocznika wc krwi na wydziclanie związków azotowych do izolowanych części jelita ślepego i okrężnicy badano podając zwierzętom dożylnie co godzinę przez 5 godzin po $40 \mathrm{ml} 7,5 \%$ roztworu mocznika, zwiększając w ten sposób stopniowo jego poziom we krwi z 11 do $26 \mathrm{mg} \mathrm{N} / 100 \mathrm{ml}$. Ilość wydzielancgo do izolowanego jelita ślepego $\mathrm{N}$-mocznika wzrastała w tym czasie progresywnie z 2 do $11 \mathrm{mg} / \mathrm{godz}$., a do pętli okrężnicy z 2,2 do 3,3 mg/godz. 